\title{
MENJADI IBU HEBAT UNTUK MENURUNKAN PENOLAKAN IBU TERHADAP ANAK DENGAN GANGGUAN SPEKTRUM AUTIS (GSA)
}

\author{
Devia Purwaningrum ${ }^{1}$, Hepi Wahyuningsih ${ }^{2}$, Sumedi P. Nugraha ${ }^{3}$ \\ deaningrum@gmail.com, hepi.habibi@gmail.com, sumedi.nugraha@UII.ac.id
}

\begin{abstract}
Abstrak. Sikap penerimaan ibu merupakan faktor penting dalam pengasuhan terhadap anak dengan gangguan spektrum autis (GSA). Ibu yang memiliki penerimaan yang tinggi mampu mengembangkan pengasuhan yang positif dan anak mampu berkembang secara optimal. Tujuan dari penelitian ini untuk mengetahui psikoedukasi Menjadi Ibu Hebat untuk menurunkan penolakan terhadap anak dengan GSA. Partisipan adalah tiga ibu yang memiliki anak dengan GSA. Pengumpulan data menggunakan parental acceptancerejection scale (PARQ). Desain penelitian menggunakan quasi eksperimen one-group pretest-posttest. Analisis data dilakukan uji Friedman Test. Hasil uji statistik dengan uji Friedman Test menunjukkan bahwa tidak ada perbedaan yang signifikan antara sebelum dan sesudah diberikan penanganan, $q=1,000$, nilai signifikansi 0,607 ( $p>0,05)$.
\end{abstract}

Kata kunci: Psikoedukasi, Penolakan Orangtua, Gangguan Spektrum Autis (GSA)

Abstract. Mother acceptance is an important factor in caring for children with autism. A mother that has a high acceptance is capable of developing a positive parenting skill and as a result the children are able to grow optimally. This research aimed to examine the psychoeducation to be a great mother to reduce the rejection towards children with autism. The participants were three mothers who have children with autism. Data collection used the parental acceptance-rejection scale (PARQ). The study design using the experimental quasi of one-group pretest-posttest. Data analysis was conducted through the Friedman Test. The result of statistical test with Friedman Test showed no significant difference between before and after the treatment, $q=1,000$, and significance value $0,607(p>0.05)$.

Key words: Psychoeducation, rejection, parents, autism spectrum disorder (ASD). 
Orangtua memiliki kewajiban untuk bertanggungjawab terhadap anak yang dimilikinya, tak terkecualipun kepada anak dengan GSA. Tanggungjawab tersebut ditunjukkan dengan pengasuhan dan memenuhi kebutuhan anak untuk dapat bertumbuh kembang secara baik. Orangtua dalam menjalankan peran pengasuhan anak dengan GSA membutuhkan pengorbanan baik secara fisik, psikologis, finansial, dan pengetahuan untuk melakukan pengasuhan dan pendampingan anak dengan GSA. Orangtua dituntut belajar menjalankan pengasuhan melalui kegiatan kelompok (seminar), berbagi pengalaman antar orangtua, membaca buku ataupun mencoba-coba mencari cara yang sesuai dengan apa yang diharapkan dengan kebutuhan anak. Namun kenyataannya, belum semua orangtua yang memiliki anak dengan GSA dapat memiliki kesiapan dan mudah memperoleh informasi atau pengetahuan tentang GSA. Kondisi tersebut membuat orangtua terus mencoba memahami dan mengelola perilaku anak dengan GSA sesuai dengan kemampuan yang orangtua ketahui.

Diagnosis anak dengan GSA semakin tahun semakin meningkat. Di Indonesia, pada tahun 2010, diperkirakan penderita anak dengan GSA mencapai 112 ribu anak dengan usia diantara 5-19 tahun (CNN, 2017). Peningkatan tersebut perlu diimbangi dengan orangtua yang siap membimbing dan membantu anak dengan GSA berkembang. Anak dengan GSA sangat membutuhkan dukungan dan bantuan seumur hidup untuk dapat hidup mandiri dan bekerja dalam masyarakat, bersosialisasi, melakukan aktivitas, dan memenuhi tujuan hidupnya seperti mengambil keputusan hidup dan mencapai kualitas hidup yang baik (Singer \& Wang, 2016). Adapun dukungan dan bantuan tersebut berasal dari keluarga terdekat terutama ibu.

Ibu memiliki peran besar terhadap proses pengasuhan anak dengan GSA. Ibu lebih mampu memberikan waktu intensif terhadap proses pendampingan, memiliki sikap sabar, dan mampu menangani perilaku sulit anak dibandingkan pengasuhan yang diperankan oleh bapak. Hasil penelitian dari Maljaars, dkk mengemukakan bahwa ibu mampu melakukan pengasuhan positif terhadap anak dengan GSA dan mampu memberikan stimulus perkembangan serta mampu menangani perilaku sulit anak dengan GSA (Maljaars, Boonen, Lambrechts, Leeuwen, \& Noens, 2013). Oleh sebab itu, ibu memiliki peran lebih banyak dalam proses pengasuhan.

Perlakuan dan perawatan ibu yang positif kepada anak dengan GSA sangatlah penting. Perlakukan positif tersebut berhubungan dengan sikap penerimaan ibu terhadap anak dengan GSA. Ibu yang memiliki pemahaman tentang kondisi anak dengan GSA, dapat membantu ibu menemukan teknik tertentu untuk dapat membantu anak, sedangkan ibu yang tidak menerima kondisi anak dengan GSA dan kurang pemahaman tentang GSA akan cenderung memberikan respon negatif. Respon yang negatif terhadap anak ditunjukkan dengan sikap kurang perhatian ibu kepada anak dan menganggap anak mengalami cacat atau tidak bisa bicara selamanya (Rachmawaty, 2014). 
Menerima kondisi anak dengan GSA membutuhkan proses. Siegel dan Sullivan (Khun \& Carter, 2006) mengemukakan bahwa ketika ibu menerima diagnosis bahwa anak mengalami GSA, maka ibu akan mengalami pengalaman yaitu kedukaan, kaget, bingung, takut, khawatir, marah, memisahkan diri, sedih, sehingga tidak bisa memberikan pengasuhan secara positif terhadap anak dengan GSA. Twistiandayani dan Handika (2015) mengemukan bahwa ibu yang belum menerima kondisi anak dengan GSA menunjukkan sikap antara lain: tidak percaya diri, patah semangat, kecewa, mengalami insomnia, depresi, dan tidak nafsu makan. Kondisi ibu yang belum menerima dan kurangnya dukungan dari keluarga berdampak kepada penelantaran anak. Berdasarkan penjelasan di atas, dapat disimpulkan bahwa seorang ibu memiliki peran penting dalam pengasuhan yang positif, namun sebelum pengasuhan positif dilakukan ibu perlu menerima kondisi anak. Permatasari (2016) yang menunjukkan bahwa faktor yang mempengaruhi keberhasilan pengasuhan anak disabilitas adalah adanya penerimaan orangtua terkait kondisi anak, co-parenting, dukungan sosial, dan keseimbangan pengasuhan.

Rogers (Thorne, 2003) mengemukakan bahwa penerimaan merupakan dasar kebutuhan positif yang dimiliki oleh manusia baik penerimaan kepada diri sendiri ataupun kepada orang lain. Konsep penerimaan memiliki pengertian yaitu menerima kondisi tanpa syarat, dimana seseorang akan peduli terhadap orang lain tanpa dipengaruhi oleh hasil penilaian pikiran, perasaan dan perilaku orang lain. Rohner (1980) berpendapat bahwa sikap menerima berarti memberikan kehangatan, kasih sayang, serta kepedulian kepada anak.

Sebaliknya, orangtua yang memiliki penerimaan negatif ditunjukkan dengan tidak dapat menerima kenyataan bahwa anaknya mengalami GSA, tidak melakukan upaya penyembuhan atau bersikap acuh terhadap anak, bersikap tertutup terhadap orang lain tentang anaknya . Sikap penerimaan negatif dari orangtua berdampak kepada anak, misalnya anak menjadi sulit diarahkan, dididik, dan dibina yang tercermin dari munculnya perilaku anak yang sulit dikendalikan. Kondisi tersebut menyebabkan kemampuan anak mengalami kemunduran (Pancawati, 2013).

Berdasarkan hasil temuan di lapangan, menunjukkan bahwa terdapat ibu yang pernah mengikuti seminar tentang GSA namun ada pula ibu yang belum pernah mengikuti seminar ataupun mendapatkan pengetahuan lain tentang GSA. Dampaknya, ibu yang pernah memperoleh pengetahuan menjadi belajar memahami dan berusaha melakukan pengasuhan positif terhadap anak dengan GSA. Sebaliknya, ibu yang tidak memperoleh informasi tentang GSA merasa kewalahan dan kebingungan membimbing dan mengelola perilaku kurang tepat anak. Terkadang ibu menunjukkan sikap marah, mengancam, ataupun mencubit anak saat anak tidak mampu mengikuti instruksi ataupun berperilaku kurang tepat. Di sisi lain, ibu yang memiliki anak dengan GSA masih belum mempercayai bahwa anaknya mengalami GSA. Kondisi tersebut terbukti dari kondisi anaknya yang lebih berkembang dibandingkan dengan anak-anak dengan GSA lainnya. 
Selain itu, dukungan orang terdekat seperti suami, dokter, terapis, ataupun guru memberikan dampak positif terhadap proses ibu menerima anak dengan GSA. Berdasarkan penjelasan beberapa orang ibu dapat disimpulkan bahwa terdapat kurangnya pemahaman ibu tentang GSA menyebabkan ibu secara tidak sengaja telah menunjukkan sikap penerimaan negatif yang ditunjukkan dengan marah secara verbal (marah, mengancam), fisik (mencubit), dan memiliki strategi mengelola perilaku anak yang terbatas.

Patton (2004) mengemukakan bahwa kebutuhan awal orangtua dalam mengenali anak dengan GSA adalah menyadari bahwa anak tersebut unik yang memiliki banyak bakat dan mendorongnya untuk menjadi lebih baik lagi. Oleh karena itu, hal yang menjadi faktor utama sebelum orangtua dapat melakukan pengasuhan, penanganan, dan memberikan terapi yang sesuai dengan kebutuhan anak adalah dengan menerima kondisi anak. Sikap penerimaan orangtua sejalan dengan tingkat pemahaman orangtua terhadap GSA. Rachmawaty (2014) mengemukakan bahwa orangtua yang memperoleh banyak informasi tentang GSA akan merasa memperoleh manfaat sehingga mampu memberikan perlakuan yang positif terhadap anak dengan GSA. Selain itu, orangtua yang telah banyak menerima pemahaman tentang GSA lebih cepat mampu menerima kondisi anak sehingga dapat fokus menangani atau membantu anak dengan GSA.

WHO (2013) dalam pertemuan di Genewa menjelaskan bahwa anak dengan GSA memiliki kebutuhan yang beragam baik terhadap kesehatan dan pelayanan, sehingga keluarga membutuhkan pendidikan orangtua untuk dapat memberikan pengasuhan kepada anak dengan GSA. Pendidikan orangtua tersebut dapat berupa psikoedukasi, pengembangan, dan penanganan perilaku. Psikoedukasi tersebut merupakan bentuk intervensi dasar yang dapat digunakan untuk menurunkan keterbatasan yang dialami oleh anak dengan GSA. Preece dan Almond; Green, dkk (Preece \& Trajkovski, 2017) mengemukakan bahwa orangtua yang memiliki informasi yang akurat melalui psikoedukasi dapat berdampak kepada proses adaptasi keluarga, penerimaan orangtua, peningkatan pemahaman individu, dan kondisi sosial keluarga anak dengan GSA.

Berdasarkan pemaparan di atas, diketahui bahwa ibu yang telah memperoleh pengetahuan tentang kondisi anak mampu mengenali dan menggali potensi anak sehingga dapat melakukan pengasuhan yang positif, sedangkan ibu yang sedikit informasi tentang GSA berdampak kepada pengasuhan yang masih bersikap negatif terhadap anak. Oleh sebab itu, hipotesis yang diajukan dalam penelitian ini adalah ada penurunan penolakan ibu terhadap anak dengan GSA antara sebelum dan sesudah diberikan psikoedukasi menjadi orangtua hebat. 


\section{METODE}

Variabel bebas dalam penelitian ini adalah psikoedukasi menjadi ibu hebat. Materi psikoedukasi dikemas dalam bentuk kegiatan diskusi, pemberian handout materi, menayangan video dan gambar. Materi ini bertujuan untuk meningkatkan pemahaman ibu tentang gambaran anak dengan GSA, mengenali perkembangan anak dengan GSA, memahami perilaku dan mengetahui strategi pengelolaan perilaku. Variabel terikat dalam penelitian ini adalah penurunan penolakan ibu terhadap anak dengan GSA.

Alat pengumpulan data yang digunakan dalam penelitian ini adalah wawancara dan kuesioner. Wawancara dikumpulkan pada awal proses penelitian yang bertujuan sebagai data awal dan akhir setelah penelitian sebagai bentuk tindak lanjut dari penanganan yang diberikan kepada partisipan yang meliputi pemikiran dan perasaan setelah mengikuti penanganan yang diberikan. Sedangkan kuesioner yang digunakan adalah kuesioner penerimaan dan penolakan orangtua menurut Rohner (Gomez \& Suhaimi, 2014) dengan tujuan ingin mengetahui perilaku orangtua dalam melakukan pengasuhan kepada anak yaitu perilaku penerimaan atau perilaku penolakan. Adapun aspek penerimaan-penolakan orangtua, yaitu kehangatan atau kasih sayang (warm/affection), permusuhan atau kekerasan (hostility/aggression), pengabaian (indifference/neglect), dan penolakan (indifference/rejection).

Adapun jumlah skala tersebut memiliki total aitem 24 aitem dengan menggunakan skala Likert dengan penilaian skor bergerak 4 = tidak benar sampai $1=$ selalu atau sebaliknya, karena sifat pernyataan unfavourable (aspek tidak sesuai dengan yang ingin diukur) dan favourable (sesuai dengan aspek yang diukur). Alat ukur penerimaan-penerimaan orangtua telah dilakukan tryout preliminary. Alat ukur memiliki koefisien reabilitas alpha sebesar 0,740. Periantalo (2017) menjelaskan bahwa koefisiensi korelasi 0,61-0,80 masuk dalam kategori kuat. Hal tersebut menunjukkan bahwa alat ukur penerimaanpenolakan orangtua memiliki reliabilitas yang kuat yang berarti kemungkinan besar memiliki hubungan antar variabel.

Pendekatan yang digunakan dalam penelitian ini adalah pendekatan kuantitatif. Metode penelitian yang digunakan adalah quasi-exsperimental. Rancangan penelitian yang digunakan adalah one group pretest-posttest design. Partisipan dalam penelitian ini adalah ibu yang memiliki anak dengan GSA. Karakteristik partisipan dalam penelitian ini memiliki skor penolakan tinggi dan sedang. Partisipan berjumlah tiga orang. Teknik analisis data yang akan digunakan dalam membuktikan secara kuantitatif dengan bantuan SPSS (Statistical Package for The Social Sciences) for Windows versi 16.0. Adapun pengujian hipotesis akan menggunakan uji statistik non parametrik yaitu uji FriedmanTest yang bertujuan untuk digunakan untuk mengetahui perbedaan skor lebih dari dua kelompok sampel yang saling berhubungan. 
Adapun prosedur pelaksanaan psikoedukasi terdiri dari beberapa langkah yaitu: pertama melakukan uji coba kuesioner untuk mendapatkan validitas dan reabilitas kuesioner dan hasil data dianalisa. Kuesioner disebar di sekolah inklusi dan SLB khusus autis. Selanjutnya mencari partisipan penelitian yang sesuai dengan kriteria. Proses dilanjutkan dengan memberikan penjelasan kepada partisipan tentang proses penanganan yang akan diberikan dan mengisi informed consent. Sedangkan penyusunan modul psikoedukasi dilakukan dengan meminta professional judgment kepada psikolog, guru pendidik anak dengan GSA, dan orangtua yang memiliki anak dengan GSA (diluar dari partisipan penelitian). Adapun materi yang diberikan yaitu: pertama gambaran umum tentang GSA. Kedua, gambaran perkembangan anak dengan GSA yang terdiri dari perkembangan dan startegi mengembangkan kemampuan komunikasi, sosial-emosi, sensorik, dan kognitif. Ketiga, mengenali perilaku anak dan strategi mengelola perilaku anak. Materi psikoedukasi disampaikan oleh psikolog yang memahami dunia anak dengan GSA dari pusat layanan autis (PLA) Kulon Progo.

\section{HASIL}

Berdasarkan hasil penghitungan statistik, menunjukkan bahwa ada perubahan antara sebelum dan sesudah diberikan psikoedukasi.

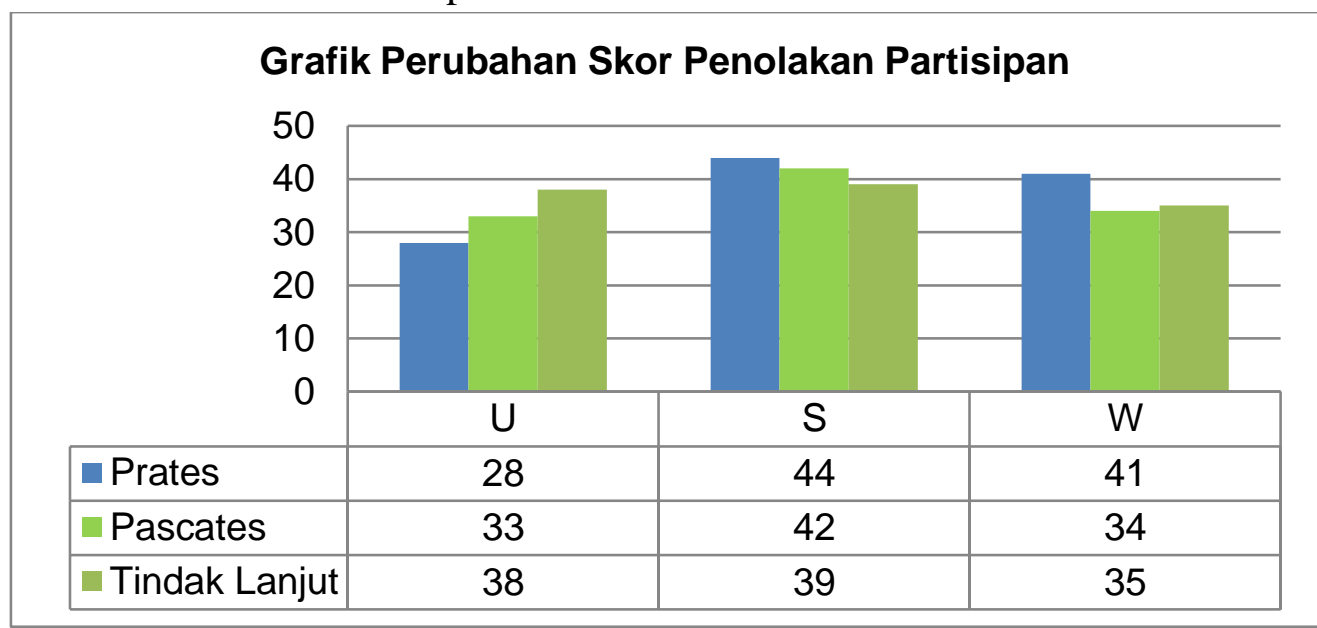

Gambar 1. Grafik Perubahan Pra-Pasca tes-Tindak Lanjut Skor Penerimaan Partisipan

Berdasarkan Gambar 1. menujukkan bahwa terdapat penurunan skor penolakan terhadap dua partisipan yaitu partisipan S dan W. Partisipan S memperoleh skor penolakan prates 44 sedangkan skor pasca pemberian psikoedukasi memperoleh skor 42. Artinya, ada penurunan skor penolakan ibu terhadap anak dengan GSA. Sedangkan partisipan W menunjukkan skor prates sebesar 41 dan mengalami penurunan skor 34 setelah psikoedukasi diberikan. Hal ini didukung dengan hasil skor yang terus menurun saat tindak lanjut. Sehingga pada dua partisipan diatas menunjunkkan penurunan penolakan terhadap anak dengan GSA. Sedangkan partisipan U mengalami peningkatan penolakan yang ditunjukkan dengan skor prates 28 dan terus meningkat pasca pemberian psikoedukasi dan tindak lanjut. 
Berdasarkan uji hipotesis dilakukan untuk mengetahui apakah ada perbedaan skor pra intervensi dan pasca intervensi penelitia menggunakan analisis uji Friedman test. Hal ini dilakukan karena jumlah partisipan dalam penelitian terdiri dari tiga orang sehingga tidak memenuhi standar asusmsi untuk uji parametrik.

Tabel 1.

Friedman Test

\begin{tabular}{ll}
\hline Chi-Square & 1,000 \\
Asymp. Sig. & 0,607 \\
\hline
\end{tabular}

Berdasarkan tabel di atas, menyajikan bahwa memiliki $\mathrm{q}=1,000$ dengan nilai signifikan 0,607 (p>0,05). Dengan demikian hipotesis penelitian Menjadi Ibu Hebat dapat meningkatkan penerimaan ibu terhadap anak dengan GSA" ditolak.

Berdasarkan hasil wawancara akhir diketahui bahwa penurunan penolakan dua partisipan dikarenakan adanya dukungan keluarga terutama dalam memberikan pengasuhan kepada anak dengan GSA setelah ibu berbagi informasi tentang psikoedukasi menjadi ibu hebat kepada keluarga. Sedangkan satu partisipan yang memperoleh skor penolakan naik disebabkan munculnya kehawatiran ibu dalam menangani terhadap anak dengan GSA di waktu yang akan datang.

\section{DISKUSI}

Berdasarkan hasil analisis data menunjukkan bahwa hipotesis peneliti yaitu menjadi orangtua hebat untuk menurunkan penolakan ibu terhadap anak dengan GSA tidak diterima. Hal ini menunjukkan bahwa psikoedukasi menjadi orangtua hebat belum mampu terbukti secara efektif dapat menurunkan skor penolakan ibu terhadap anak dengan GSA dalam penelitian ini.

Berdasarkan peneliti sebelumnya menunjukkan bahwa memberikan pengetahuan dan keterampilan kepada orangtua dapat meningkatkan penerimaan orangtua yang memiliki anak dengan GSA. Futuhiyat (2004) menjelaskan bahwa terdapat hubungan antara pengetahuan yang dimiliki orangtua terhadap anak penyandang GSA. Hasil penelitian tersebut menunjukkan bahwa semakin tinggi pengetahuan orangtua tentang GSA maka sikap penerimaan orangtua semakin tinggi. Hal tersebut sejalan dengan penelitian Rochmani (2014) yang melakukan penelitian tentang penerimaan orangtua dengan memberikan intervensi yaitu media literasi kesehatan "Care-Autis" dengan dukungan internet. Adapaun responden dalam penelitian ini adalah tiga orang ibu yang memiliki anak dengan GSA berusia 3-8 tahun. Hasilnya menunjukkan bahwa literasi "Care-Autis" dapat meningkatkan penerimaan orangtua yang memiliki anak dengan GSA. 
Pertimbangan lain tidak terbuktinya hipotesis antara lain sejalan dengan teori perubahan perilaku. DiClemente, dkk; Prochaska dan DiClemente, dkk (Prochaska, DiClemente, \& Norcross, 1992) mengemukakan bahwa sebelum individu melakukan tindakan ada beberapa tahap yang perlu dipenuhi sebelumnya yaitu tahap precontemplation, contemplation, dan preparation. Partisipan dalam penelitian ini telah mengetahui anak telah didiagnosis GSA dan berusaha untuk memaksimalkan serta mencari cara tindakan yang tepat kondisi tersebut berada pada tahap persiapan (preparation). Waktu melalui tahapan persiapan membutuhkan waktu satu bulan selanjutnya dengan adanya perencanaan kegiatan seperti, bergabung pada pusat kesehatan, membeli buku pengelolaan, melakukan kosultasi, dll (Prochaska \& Velicer, 1997). Sejalan dengan penelitian Jaccard, dkk (Olin, et al., 2010) menambahkan bahwa salah satu penentu perubahan perilaku adalah dengan memberikan pengetahuan dan keterampilan berperilaku. Oleh sebab itu, pemberian psikoedukasi belum berdampak langsung terhadap tahap tindakan orangtua terhadap penurunan pengasuhan karena orangtua membutuhkan waktu untuk menyusun rencana untuk dapat melakukan perubahanperubahan perilaku yang sesuai dengan kondisi anak dengan GSA.

Di sisi lain, peneliti perlu mengkaji tentang faktor budaya dan agama dalam proses pengasuhan anak. Masyarakat Indonesia masih memegang dan menjunjung tinggi erat budaya ketimuran, terutama dalam mendidik dan melakukan pengasuhan kepada anak. Hurlock (Valentia, Sani, \& Anggreany, 2017) menjelaskan bahwa faktor nilai budaya yang dianut oleh orangtua mempengaruhi cara dan sikap orangtua dalam memberikan pengasuhan kepada anak. Valentia, Sani, dan Anggreany (2017) dalam penelitiannya mengemukakan bahwa nilai budaya dan religiusitas yang dianut oleh orangtua digunakan sebagai dasar pedoman melakukan pengasuhan kepada anak. Pandangan orangtua bahwa orangtua memiliki tugas dan tanggungjawab untuk dapat membesarkan anak sekalipun memiliki anak dengan berkebutuhan khusus. Sehingga, sekalipun ibu menunjukkan sikap penolakan namun tidak memperlihatkan bentuk nyatanya kepada anak.

Symonds (1938) mengemukakan bahwa penolakan adalah salah satu bentuk kompensasi yang dilakukan oleh orangtua yang ditunjukkan dengan memberikan kasih sayang secara lebih, terlalu melindungi, dan lain-lain. Sikap penolakan yang orangtua lakukan terkadang ditutupi dengan kondisi yang penuh dengan kasih sayang dan hubungan yang menyenangkan terhadap anak. Orangtua beranggapan sesekali memberikan kritikan ataupun hukuman adalah sikap yang wajar, namun sikap tersebut dianggap salah satu gejala permusuhan dan ketidaksukaan. Oleh karena itu, penggunaan alat ukur penerimaan-penolakan orangtua dinilai kurang efektif dapat menggambarkan kondisi partisipan dalam penelitian ini.

Berdasarkan temuan lapangan menunjukkan, bahwa salah satu partisipan yang memiliki skor meningkat dari skor sebelum diberikan psikoedukasi adalah karena berkurangnya dukungan dari ahli dalam hal ini adalah guru dan perasaan cemas terhadap masa depan 
anak. Tussofa (2015) mengemukakan bahwa kecemasan yang terjadi secara terus menerus akan menyebabkan stres sehingga tidak mampu berperan secara maksimal terhadap pengasuhan terhadap anak. Catur (2017) menambahkan bahwa stress dalam pengasuhan memiliki pengaruh terhadap penerimaa ibu yang memiliki anak dengan GSA. Selain itu, Sarasvati menjelaskan bahwa dukungan para ahli dan masyarakat juga ikut mempengaruhi penerimaan ibu terhadap anak (Rachmayanti \& Zulkaida, 2007).

Sebaliknya, dua partisipan lainnya mengalami penurunan skor penolakan karena adanya faktor pendukung yaitu suami. Hadirnya suami dalam proses pengasuhan ibu terhadap anak dengan GSA membuat ibu semakin yakin dengan pengasuhan dan mudah merencanakan startegi pengembangan untuk anak. Sarasvati (Rachmayanti \& Zulkaida, 2007) mengemukakan bahwa dukungan keluarga besar merupakan salah salah satu faktor menunjang penerimaan orangtua terhadap anak. Berdasarkan penjelasan tersebut diketahui bahwa peningkatan penolakan yang dialami oleh salah satu responden disebabkan karena adanya kecemasan yang sedang dialami terutama berhubungan dengan masa depan anak dan dukungan dari ahli dalam hal ini adalah guru di sekolah. Dua partisipan lainnya mengalami penurunan skor penolakan karena adanya dukungan dari keluarga sehingga dapat memaksimalkan pengasuhan terhadap anak dengan GSA.

\section{SIMPULAN DAN IMPLIKASI}

Berdasarkan hasil penelitian ini membuktikan bahwa psikoedukasi menjadi ibu hebat belum efektif bisa digunakan untuk menurunkan penolakan ibu terhadap anak dengan GSA, namun mampu memberikan informasi kepada partisipan tentang gambaran dan perkembangan anak dengan GSA. Terdapat beberapa faktor yang menyebabkan penurunan penolakan ibu terhadap anak dengan GSA. Dukungan keluarga dan para ahli serta masyarakat dapat menjadi faktor menyebab ibu dapat segera menurunkan penolakan terhadap anak dengan GSA. Faktor budaya dan religiusitas ikut berpengaruh terhadap proses pengasuhan ibu, sekalipun ibu belum mampu menerima kondisi anak namun tetap dapat memberikan pengasuhan yang layak kepada anak dengan GSA.

Saran untuk peneliti selanjutnya adalah peneliti perlu melakukan kontrol terhadap usia anak dengan GSA, lama ibu mengasuh anak dengan GSA, tingkatan hambatan anak dengan GSA, menambah jumlah partisipan, pendidikan akhir orangtua, dan seberapa sering orangtua mengikuti kegiatan seminar khususnya tentang autis. Selain itu, psikoedukasi sebaiknya disampaikan kepada kedua orangtua, wali, ataupun pengasuh anak dengan GSA. Harapannya semua anggota keluarga atau pengasuhan memperoleh informasi yang sama untuk dapat menerapkan proses pengasuhan bersama-sama. 


\section{REFERENSI}

CNN, Indonesia. (2017). Diet khusus untuk penyandang autisme. Diperoleh 7 September 2017.

Futuhiyat. (2004). Hubungan antara pengetahuan orangtua tentang GSA dengan sikap penerimaan orangtua terhadap anak penyandang autistic. Jakarta: UIN Syarif Hidayatullah.

Gomez, R., \& Suhaimi, A. F. (2014). Malaysian parent ratings of the parental acceptance-rejection questionnaire-short form: factor structure and invariance across girls and boys and mothers and fathers. Parenting: Science and Practice ,14, 195-214.

Catur, N.W.M. (2017). Hubungan antara stres pengasuhan dan penerimaan orangtua terhadap kualitas hidup pada ibu dengan anak gangguan spektrum autisme.Thesis tidak dipublikasikan. Yogyakarta: Universitas Gadjah Mada.

Khun, J. C., \& Carter, A. S. (2006). Maternal self-efficacy and associated parenting cognitions among mother of children with autism. American Journal of Orthopychiatry, 76(4), 564-575.

Maljaars, J., Boonen, H., Lambrechts, G., Leeuwen, K. V., \& Noens, I. (2013). Maternal parenting behavior and child behavior problems in families of children and adolescents with autism spectrum disorder. J Autism Dev Disord , 44(3), 501-512.

Olin, S. S., Hoagwood, K. E., Rodriguez, J., Ramos, B., Burton, G., Penn, M., et al. (2010). The application of behavior change theory to family-based services: improving parent empowerment in children's mental health. J Child Fam Stud, 19, 462-470.

Pancawati, R. (2013). Penerimaan Diri dan Dukungan Orangtua Terhadap Anak Autis. eJournal Psikologi , 1(1), 38-47.

Patton, S. (2004). Welcoming children with special needs: a guidebook for faith communities. Boston: Unitarian Universalist Assiciation.

Periantalo, J. (2017). Statistik dasar untuk psikologi. Yogyakarta: Pustaka Pelajar.

Permatasari, D. (2016). Humanistic-brief group therapy untuk meningkatkan penerimaan ibu yang memiliki anak disabilitas. Thesis tidak dipublikasikan.Yogyakarta: Universitas Gadjah Mada.

Preece, D., \& Trajkovski, V. (2017). Parent education in autism spectrum disorder - a review of the literature. Hrvatska revija za rehabilitacijska istraživanja , 53(1), 128-138.

Prochaska, J. O., \& Velicer, W. F. (1997). The Transtheoretical Model of Health Behavior Change. An J Health Promot, 12(1), 38-48.

Prochaska, J. O., DiClemente, C. C., \& Norcross, J. C. (1992). In Search of How People Change Applications to Addictive Behaviors. American Psychologist , 47(9), 1102-1114.

Rachmawaty, R. D. (2014). Pemahaman Autisme Pada Orangtua yang memiliki anak autis di lembaga potensi perkembangan anak "triple a" malang. Psikovidya , $18(1), 40-67$. 
Rachmayanti, S., \& Zulkaida, A. (2007). Penerimaan diri orangtua terhadap anak autism dan perannya dalam terapi autisme. Jurnal Psikologi , 1(1), 7-17.

Rohmani, K. W. (2014). Care-autis: literasi dengan dukungan internet untuk meningkatkan penerimaan orangtua. Thesis tidak dipublikasikan.Yogyakarta: Universitas Gadjah Mada.

Rohner, R. P. (1980). Worldwide tests of parental acceptance-rejection theory: an overview. Behavior Science Research , 1, 1-21.

Singer, G. S., \& Wang, M. (2016). Supporting families of children with developmental disabilities: evidence-based and emerging practice. USA: Oxford University Press.

Symons, P. M. (1938). A study of parental acceptance and rejection. The American Journal Of Orthopsychiatry, 679-688.

Thorne, B. (2003). Carl Rogers Second Edition. Oaks: SAGE Publications.

Tussofa, M. (2015). Tingkat kecemasan ibu yang memilikianak autis usia 6-7 tahun di sekolah luar biasa semesta mojokerto. Diakses di repository.poltekkesmajapahit.ac.id/index.php/PUB-

KEP/article/download/492/404.

Twistiandayani, R., \& Handika, S. R. (2015). Hubungan dukungan keluarga dengan penerimaan ibu yang mempunyai anak autis. Journals of Ners Community , 6(2), 143-149.

Valentia, S., Sani, R., \& Anggreany, Y. (2017). Hubungan antara resiliensi dan penerimaan. Jurnal Psikologi Ulayat, 4, 43-57.

WHO. (2013). Autism spectrum disorders \& other developmental disorders: from raising awareness to building capacity. Genewa: WHO Production Service. 